\title{
Temporal Changes in Cereal Aphids (Hemiptera: Aphididae) Populations in Northern Rio Grande do Sul, Brazil
}

\author{
Adriane Rebonatto ${ }^{1}$, José R. Salvadori ${ }^{1} \&$ Douglas Lau ${ }^{2}$ \\ ${ }^{1}$ School of Agronomy and Veterinary Medicine, Passo Fundo University, Passo Fundo, Brazil \\ ${ }^{2}$ Embrapa Trigo, Passo Fundo, Brazil \\ Correspondence: Douglas Lau, Embrapa Trigo, Passo Fundo, Rodovia BR 285, km 294 CEP 99001-970, Brazil. \\ Tel: 55-(54)-3316-5832. E-mail: douglas.lau@embrapa.br
}

Received: June 16, 2015 Accepted: July 20, 2015 Online Published: September 15, 2015

doi:10.5539/jas.v7n10p71

URL: http://dx.doi.org/10.5539/jas.v7n10p71

\begin{abstract}
Cereal aphids (Hemiptera: Aphididae) are economically important pests in all wheat-producing regions of Brazil and about eight species can be found in wheat crops. Aphids acquired the condition of severe pest in wheat in the 1970s, due to the emergence of Metopolophium dirhodum and Sitobion avenae. A successful biological control program of wheat aphids was introduced in southern Brazil in 1978. This study describes temporal changes in aphid populations in a wheat producing area in the northern region of Rio Grande do Sul (RS) state, Brazil. Data from weekly samples (water traps of Moericke type) for the current (May to November 2008, 2009 and 2010) population frequency of each species was compared with 1970s populations. In addition, their seasonal fluctuations and the influence of rainfall and temperature on their populations were estimated. The species collected, and their frequencies, were as follows: Rhopalosiphum padi (57.6\%), Sitobion avenae (31.0 \%), Schizaphis graminum (7.7\%), Metopolophium dirhodum (1.4\%), Rhopalosiphum rufiabdominalis (0.9\%), Rhopalosiphum maidis $(0.6 \%)$, Sipha maydis (0.4\%) and Sipha flava $(0.4 \%)$. Aphids populations in winter cereals in northern RS have changed radically. The high populations of $M$. dirhodum in wheat in 1970s have been reduced to such levels that rarely have been found. Nowadays, $R$. padi was the predominant species. When the rainfall remained between $0-20 \mathrm{~mm}$ and temperatures between $15-20{ }^{\circ} \mathrm{C}$, aphid populations were more numerous than the average for the sampling period.
\end{abstract}

Keywords: Rhopalosiphum padi, Sitobion avenae, Schizaphis graminum, Metopolophium dirhodum, Triticum aestivum

\section{Introduction}

Aphids (Hemiptera: Aphididae) are economically important pests in all wheat-producing regions of Brazil (Lau et al., 2009). They cause direct damage to crops by inserting their stylet on plant cells and tissues, triggering reactions and cell death by the toxins and enzymes in their saliva, and by sucking plant sap. Indirect damages result from the transmission of Barley/Cereal yellow dwarf virus (B/CYDVs) the causal agents of yellow dwarf disease (YDD), a frequent disease in wheat and oat fields in southern Brazil (Parizoto et al., 2013). YDD - like symptoms have been reported in the country since 1929 and Caetano (1968) first described its etiology.

There were records of Schizaphis graminum (Rondani, 1852) - the greenbug aphid - in Brazilian wheat crops in the first half of the last century (Reiniger, 1941), but was in the 1960s, coinciding with the increase in wheat growing area in southern Brazil and the emergence of Sitobion (= Macrosiphum) avenae (Fabricius, 1794) - the english-grain aphid - and Metopolophium (= Acyrthosiphum) dirhodum (Walker, 1849) - the rose-grass aphid (Corseuil, 1959; Fehn, 1970), which aphids acquired the condition of severe pest in wheat. Based on a survey conducted from 1967 to 1972 in southern Brazil, M. dirhodum was the predominant species and main vector of BYDV and less frequently were also found Rhopalosiphum padi (Linnaeus, 1758) - the bird cherry-oat aphid and eventually Rhopalosiphum rufiabdominalis (Sasaki, 1899) - the rice-root aphid, and Sipha flava (Forbes, 1884) - the yellow-sugarcane aphid (Caetano, 1972, 1973). Recently, Sipha maydis - the black-cereal aphid was reported in Brazilian wheat crops (Pereira et al., 2008).

Aphid species, native to Europe and Asia, were introduced free of effective natural enemies and additionally found the wheat crops area expanding. The food availability, favorable weather and ineffective natural biological 
control led to a population explosion and wide dispersion of these insects that soon became the main pests of wheat and other winter cereals crops. This occurred in the extreme south of the country, especially in the states of Rio Grande do Sul (RS), Santa Catarina (SC) and Paraná (PR). Aphids have become limiting to wheat production in the southern region occurring at an alarming level, causing drastic reductions in productivity. In Rio Grande do Sul, in 1971, was recorded the occurrence of 150 individuals of S. avenae/spike (Kober, 1972). In Paraná, in 1974, 183.7 and 167.4 aphids/plant peaks were observed for M. dirhodum and S. avenae, respectively (Pimenta \& Smith, 1976). On the plateau of Rio Grande do Sul, in 1974 and 1976 in plots without control aphids, wheat yields suffered losses of up to $88 \%$ and $56 \%$, respectively (Salvadori \& Salles, 2002). It was estimated that the damage caused by aphids on wheat production in southern Brazil were more than $20 \%$ in the period 1967-72 and that the incidence of infested plants reached 100\% in some areas (Caetano, 1973). The control of wheat aphids was done without the integrated management criteria, through the intensive use of chemical insecticides.

In this scenario, the wheat aphids biological control program in Brazil was designed by the National Center of Wheat Research (Embrapa Wheat), unit of Brazilian Agricultural Research Corporation (Embrapa), targeting $M$. dirhodum and S. avenae, whose population levels and damage to culture have become alarming in the 1970s. The program was developed from 1978 with the support of FAO and the University of California - Berkeley, USA and collaboration of many others national and international institutions. To mitigate the problem, classical biological control was adopted, introducing natural enemies, especially parasitoids, coming mainly from regions of origin of the target pests (Salvadori \& Salles, 2002). After the introduction of the biological control program the occurrence of the aphids has decreased, and the relative importance of each species has changed. Evidence shows that $R$. padi populations have expanded on winter cereals, both in Rio Grande do Sul and Paraná states becoming one of the predominant species on those crops (Lau et al., 2009).

Since the 1980s, especially after the biological control programs that were established, systematic surveys on the status of southern wheat aphid populations have not been conducted. During this period, changes in the agricultural production system as increased areas with oat crops, and adoption of new technologies (cultivars, no tillage farming system, etc.), besides climate change, may have altered the relative importance of aphid pest species and their seasonality.

Aphid populations often have a widely year-to-year fluctuations. These populations are affected simultaneously by biotic and abiotic factors, but questions remain regarding the main factors that cause this variation, especially natural enemies (Leslie et al., 2009). Weather conditions are considered the main variables that affect the dynamics of aphid populations (Risch, 1987). The incidence of prolonged or heavy rainfall has been mentioned as a limiting factor for the growth of aphid populations (Dixon, 1977; Gassen, 1984). Temperature is also another dominant abiotic factor. For aphids temperature has been shown to be a reliable indicator of future population growth (Brabec et al., 2014; Finlay \& Luck, 2011). Mild temperatures, $18-25{ }^{\circ} \mathrm{C}$, and rain shortages create conditions that are ideal for aphid reproduction and development (Gassen, 1984).

The aim of this study was describe temporal changes in cereal aphids populations in winter crops in the north of Rio Grande do Sul state, Brazil. The current aphids populations (data from Coxilha) were compared with populations of the 1970s (data from Passo Fundo, $12 \mathrm{~km}$ away). We also investigated the relationship between the oscillations of the populations of aphids and temperature and precipitation.

\section{Material and Methods}

This research was conducted in a field area of approximately $5,500.0 \mathrm{~m}^{2}$ located at Coxilha - Rio Grande do Sul state $\left(710.0 \mathrm{~m}\right.$ altitude, $28^{\circ} 11^{\prime} 42.8^{\prime \prime} \mathrm{S}$ and $\left.52^{\circ} 19^{\prime} 30.6^{\prime \prime} \mathrm{W}\right)$, representative of the Middle Plateau wheat crop region in the north of Rio Grande do Sul. The sampling period was from May to November 2008, 2009 and 2010 (26 weeks/year). Data on rainfall and air temperature were obtained from the main meteorological station of Passo Fundo, RS $\left(28^{\circ} 15^{\prime} \mathrm{S}, 52^{\circ} 24^{\prime} \mathrm{W}, 684 \mathrm{~m}\right)$ located $12 \mathrm{~km}$ from the experimental area.

The field was conducted in no-till farming system. Oat (Avena strigosa Schreb, var Agrozebu) was sown 15 to 20 days preceding the $1^{\text {st }}$ sowing of wheat. It was sown in three, $113 \mathrm{~m}$ long and $4.5 \mathrm{~m}$ wide rows, one on each side of the experimental area, and one at the middle. The wheat, Triticum aestivum L., was sown between the oat rows, and was divided into two parts. The first one was sown up to June 15th, and the second one after 30 days (July).

The winged aphid population was monitored with water traps of Moericke type (yellow tray, $45 \mathrm{~cm}$ long $\times 30 \mathrm{~cm}$ wide $\times 4.5 \mathrm{~cm}$ tall). Each tray had three side holes $(5 \mathrm{~mm}$ diameter), near the border, protected by a fine screen to prevent leakage and loss of solid content during the rains. 
Nine traps were distributed throughout the three oat rows (three for each row) and 18 traps on the edges of the wheat plots (nine for each sowing date). The traps were positioned only after emergence of the seedlings, and leveled approximately $20 \mathrm{~cm}$ from the ground, with the aid of bricks. Near the trap, a gap of a $1.5 \mathrm{~m} \times 1.5 \mathrm{~m}$ was opened to make it more visible.

Every week, each trap received 2.0 liters of solution prepared with water, $40 \%$ formalin $(0.3 \%)$ and detergent $(0.2 \%)$. If necessary the solution was replenished during the week. Every seven days, the solid content of the trays, separated from the solution through the sieve, was collected. The biological material was packed in a glass bottle with $70 \%$ alcohol. In the laboratory, with the aid of a stereoscopic microscope, the aphids were separated, identified and counted. Species identification was performed by the aid of taxonomic keys (Blackman \& Eastop, 1984; Stoetzel, 1987; Stoetzel \& Miller, 2001; Pereira et al., 2009).

The current frequencies of aphid species were determined. In order to analyze aphid population changes after the biological control program that was established in Southern Brazil, the mean numbers of aphid/trap/year of the current population were compared with the aphid population from May to November of 1971 to 1977 . These data were obtained in the same region $\left(28^{\circ} 15^{\prime} \mathrm{S}, 52^{\circ} 24^{\prime} \mathrm{W}\right)$ and using the similar traps $(30 \mathrm{~cm}$ long $\times 20 \mathrm{~cm}$ wide $\times 5 \mathrm{~cm}$ tall) (V. R. Caetano \& V. R. Caetano, 1978).

In order to describe patterns of variation in cereal aphid population we calculated the average number of aphids/trap/week, which was used to generate distribution curves of the various species throughout the sampling period. The numbers of aphids were confronted with data on accumulated rainfall during the week prior to collecting, and the average temperature during that period. In order to infer the conditions that allowed aphid populations to grow, classes of frequency for these two climatic variables were established, considering the distribution of all weekly samplings (78) with respect to the weeks in which aphid populations were above average. We then calculated the deviations from the mean with respect to the total population.

\section{Results and Discussion}

The following aphids species were associated with cereals during the entire sampling period (May to November 2008, 2009 and 2010): R. padi (57.6\%), S. avenae (31.0\%), S. graminum (7.7\%), M. dirhodum (1.4 \%), R. rufiabdominalis $(0.9 \%)$, R. maidis $(0.6 \%)$, S. maydis (Passerini, 1860) $(0.4 \%)$ and S. flava (Forbes, 1884) (0.4\%). $R$. padi was the predominant species. This result is consistent with recent surveys in Brazil, in regions where winter cereals are cultivated (Silva et al., 2004; Alves et al., 2005; Lau et al., 2009).

The current frequencies of the various aphid species are very different from those observed in the 1970s, before the implementation of the biological control program of wheat aphids pests (Salvadori \& Salles, 2002). When the averages from the 1971 to 1977 (V. R. Caetano \& V. R. Caetano, 1978) are compared with current data (2008-2010, for the period from May to November - 26 weeks of sampling), it is evident that the current total aphid population is less than $2 \%$ of the total population in the 1970s (Table 1). Most of this reduction is due to changes in the population of M. dirhodum. In the 1970s, this species corresponded, on average, to $97 \%$ of the aphid population. Currently, it represents around $2 \%$ of it. Conversely, $R$. padi is currently the most abundant species $(57.6 \%)$, whereas in the 1970 s it represented less than $1 \%$ of the aphid population on wheat. With the deep decline in the population of $M$. dirhodum, other species have come to represent a greater proportion of the total aphid populations, especially $S$. avenae and S. graminum. However, their populations, in absolute terms, have either decreased (S. avenae) or are equivalent to those of the 1970s (S. graminum). The only species that has undoubtedly increased its representation is R. padi. S. maydis, a species that was not present in Brazil in the 1970s, is excluded from this comparison. Reported in Brazil for the first time in 2006 (Pereira et al., 2008), $S$. maydis did not exceed $0.5 \%$ of the total population in our samples (2008-2010). 
Table 1. Comparison between mean number of aphid/trap/year of the populations of aphids associated wheat between 1970 (71 to 77$)^{1}$ and $2000(8,9 \text { and } 10)^{2}$

\begin{tabular}{|c|c|c|c|c|}
\hline \multirow{2}{*}{ Aphids species } & \multicolumn{2}{|c|}{1970} & \multicolumn{2}{|c|}{2000} \\
\hline & Number & Percentage & Number & Percentage \\
\hline Metopolophium dirhodum & 3690.9 & 96.8 & 1.0 & 1.4 \\
\hline Rhopalosiphum padi & 10.6 & 0.3 & 41.1 & 57.6 \\
\hline Schizaphis graminum & 3.6 & 0.1 & 5.5 & 7.7 \\
\hline Sitobion avenae & 95.4 & 2.5 & 22.1 & 31.0 \\
\hline Rhopalosiphum maidis & 2.4 & 0.0 & 0.4 & 0.6 \\
\hline Rhopalosiphum rufiabdominalis & 10.6 & 0.3 & 0.6 & 0.9 \\
\hline Sipha flava & 0.5 & 0.0 & 0.3 & 0.4 \\
\hline Sipha maydis & 0.0 & 0.0 & 0.3 & 0.4 \\
\hline Total & 3814.0 & 100.0 & 71.3 & 100.0 \\
\hline
\end{tabular}

Note. ${ }^{1}$ Based on data from V. R. Caetano and V. R. Caetano (1978); ${ }^{2}$ Coxilha, RS (this study).

From the results obtained over three years for the four species most commonly associated with winter cereals, $R$. padi presented a bimodal temporal distribution, with population peaks in the autumn-winter and spring, and was present throughout the period (Figure 1). Previous field surveys have reported on the prevalence of $R$. padi, and its ability to settle at different times of the year in southern Brazil (Lau et al., 2009). This may be related to the adaptive plasticity of the species, which colonizes various organs of the hosts. Under field conditions, $R$. padi has been found from the roots to the reproductive organs of plants. Moreover, it occurs in different host species in southern Brazil, for instance in oat and corn. The increase in populations of $R$. padi with respect to the 1970s may be related to its capacity to colonize other cultures that have become more important since that period.

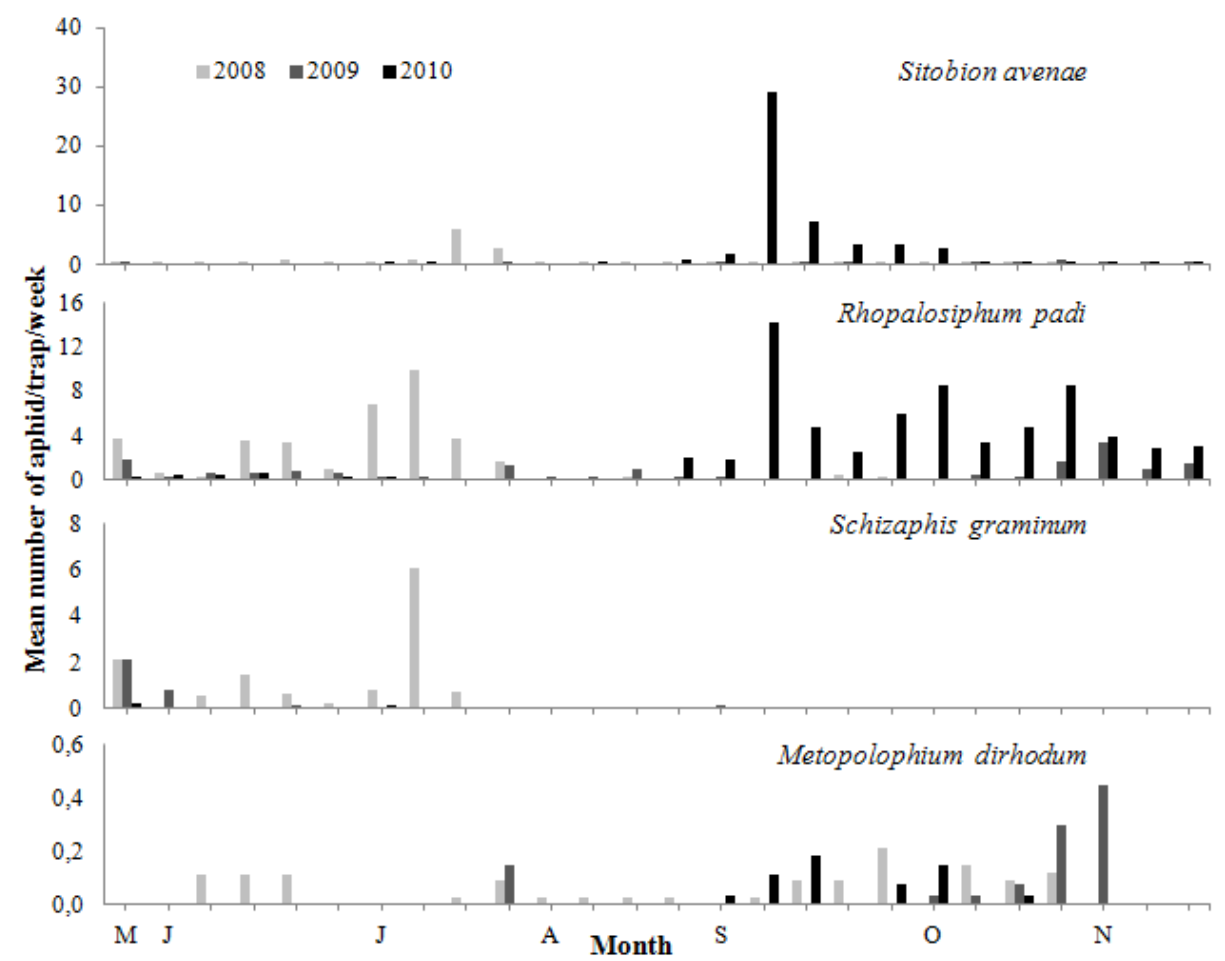

Figure 1. Mean number of aphid/trap/week of the species Rhopalosiphum padi, Sitobion avenae, Schizaphis graminum and Metopolophium dirhodum, in weekly samplings from May to November 2008, 2009 and 2010.

Coxilha, RS 
Sitobion avenae was abundant in the spring, following the same pattern of occurrence registered in the 1970s (V. R. Caetano \& V. R. Caetano, 1978) for this region. The peak population of S. avenae should be largely related to the availability of hosts in the suitable development stages for the species. Under field conditions, frequent outbreaks of $S$. avenae have been reported during earing of the wheat, regardless of the time it occurs (e.g. in July in northern Paraná).

The $S$. graminum population peaked from May to July, in the early stage of plant development. In Coxilha, the period covered by this study is not the most suitable for $S$. graminum. However, in years with mild temperatures, outbreaks of $S$. graminum have been reported, especially in autumn, on oats.

In our sampling $M$. dirhodum was detected mainly in the second semester (late winter - spring), which corresponds to the same period when the species was abundant in the 1970s survey (V. R. Caetano \& V. R. Caetano, 1978), before the biological control of aphids on wheat.

In summary, the seasonal distribution pattern observed for each of these species is similar to that described for the 1970s (V. R. Caetano \& V. R. Caetano, 1978), but the relative importance of each species has changed. The quantitative composition of the aphid populations suffered great variation in the three years of our analysis. Despite seasonal variations and the availability of hosts in suitable phenological stages, environmental conditions have affected the growth of populations.

Considering all species of cereal pests during the three years sampled, 2010 was the most favorable for aphid population growth: five times as many aphids were collected than in 2009, and twice as many than in 2008 (Figure 2). This variation can be explained by the effect of abiotic factors, such as rainfall and temperature.

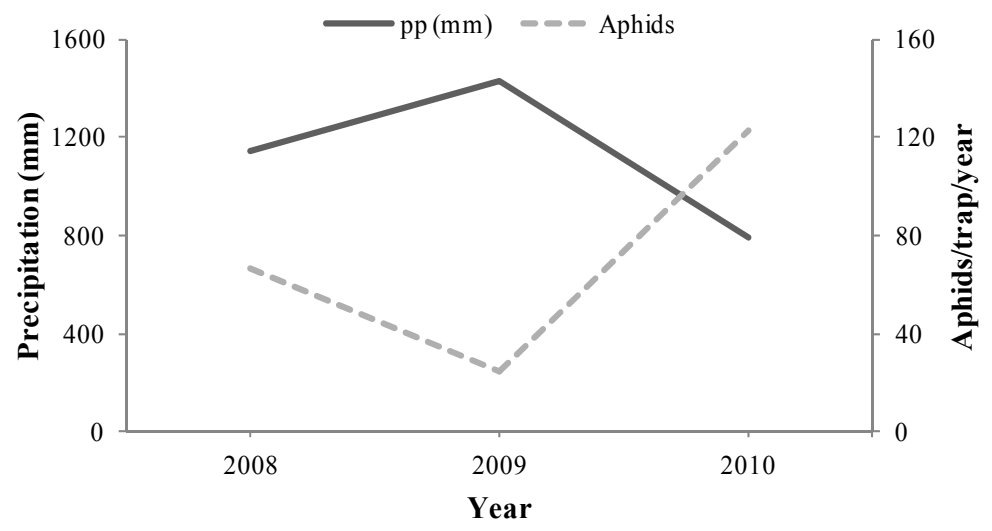

Figure 2. Accumulated precipitation/year and accumulated number of aphids/trap/year from May to November 2008, 2009 and 2010. Coxilha, RS

Rainfall was inversely correlated with aphid population sizes. During the first year of sampling, 2008, the accumulated precipitation for the sampling period was $1144.1 \mathrm{~mm}$, and the average cumulative number of aphid/trap/year was 66.4. In 2009, these values were $1425.8 \mathrm{~mm}$ and $24.5 \mathrm{aphid} /$ trap/year and in $2010,792.6 \mathrm{~mm}$ and $123 \mathrm{aphid} /$ trap/year (Figure 2). High levels of accumulated precipitation and heavy and/or prolonged rainfall limits aphid populations to low densities (Dixon, 1977; Gassen, 1984; Leslie et al., 2009). Conversely, when rainfall is low, the populations tend to increase (Walker et al., 1984). Analyzing the accumulated rainfall per week, it can be observed that on most weeks $(65.2 \%)$ when aphids were collected in numbers above the average (2.7 aphids/trap/week), rainfall was between $0-20 \mathrm{~mm}$ (Table 2). This suggests that such precipitation conditions are favorable to aphid populations, or at least do not limit them. Disregarding the exception of one sample, in which high precipitation occurred three days before sampling, the amount of aphids collected in the weeks when rainfall classes were above $60 \mathrm{~mm}$ were not above average (Table 2). However, there were periods when the low amount of aphids coincided with low rainfall, indicating that rain is not sufficient to explain the growth of aphid populations, and that other factors are involved. 
Table 2. Number and frequency of the weeks sampled (SA) with respect to the number of aphids, in different classes of accumulated weekly precipitation (pp), in the winter harvest of 2008, 2009 and 2010. Coxilha, RS

\begin{tabular}{llllll}
\hline Class pp & SA & $\mathbf{\% ~ S A ~}$ & $\mathbf{S A}>\mathbf{2 . 7 ^ { \mathbf { 1 } }}$ & $\mathbf{\%} \mathbf{S A}>\mathbf{2 . 7}$ & ${\text { Deviation } \mathbf{\%}^{\mathbf{2}}}^{\mathbf{0}-20}$ \\
$\mathbf{2 0 - 4 0}$ & 33 & 42.3 & 15 & 65.2 & -22.9 \\
$\mathbf{4 0 - 6 0}$ & 15 & 19.2 & 3 & 13.0 & 6.2 \\
$\mathbf{6 0 - 8 0}$ & 8 & 10.3 & 4 & 17.4 & -7.1 \\
$\mathbf{8 0 - 1 0 0}$ & 6 & 7.7 & 0 & 0.0 & 7.7 \\
$\mathbf{1 0 0 - 1 2 0}$ & 5 & 6.4 & 0 & 0.0 & 6.4 \\
$\mathbf{1 2 0 - 1 4 0}$ & 4 & 5.1 & 0 & 0.0 & 5.1 \\
$\mathbf{1 4 0 - 1 6 0}$ & 4 & 5.1 & 0 & 0.0 & 5.1 \\
\hline Total & 3 & 3.8 & 1 & 4.3 & -0.5 \\
\hline
\end{tabular}

Note. ${ }^{1}$ SA $>2.7$ : Number of weeks the observed aphid population was greater than the mean number of aphids during the entire sampling period (2.7 aphid/trap); ${ }^{2}$ Deviation \%: \% SA - \% SA $>2.7$.

With respect to temperature (Table 3), the 23 weeks in which the average number of aphids/trap/week was greater than the average (2.7), the most frequent thermal class was 17.5 to $20^{\circ} \mathrm{C}$, with the greatest population increase between 15 and $20{ }^{\circ} \mathrm{C}$. These results corroborate that the temperature strongly affects aphids, which become more abundant where and when the temperature is higher in the growing season of winter cereals (Caetano, 1972; Caetano, 1973; Gassen, 1984). It is noteworthy that other factors, besides the temperature, affected the population of aphids, since in some cases the number of aphids failed to increase when temperatures were favorable.

Table 3. Number and frequency of the sampled weeks (SA) with respected to the number of aphids in different classes of mean temperature $\left({ }^{\circ} \mathrm{C}\right)$, from May to November 2008, 2009 and 2010. Coxilha, RS

\begin{tabular}{llllll}
\hline Class $^{\mathbf{0}} \mathbf{C}$ & $\mathbf{S A}$ & $\mathbf{\% ~ S A ~}$ & $\mathbf{N}^{\mathbf{0}} \mathbf{S A}>\mathbf{2 . 7}^{\mathbf{1}}$ & $\mathbf{\%} \mathbf{S A}>\mathbf{2 . 7}$ & Deviation $^{\mathbf{2}}$ \\
\hline$<\mathbf{1 0}$ & 6 & 7.7 & 1 & 4.3 & 3.3 \\
$\mathbf{1 0} \mathbf{- 1 2 . 5}$ & 19 & 24.4 & 1 & 4.3 & 20.0 \\
$\mathbf{1 2 . 5}-\mathbf{1 5}$ & 15 & 19.2 & 4 & 17.4 & 1.8 \\
$\mathbf{1 5} \mathbf{- 1 7 . 5}$ & 20 & 25.6 & 7 & 30.4 & -4.8 \\
$\mathbf{1 7 . 5}-\mathbf{2 0}$ & 14 & 17.9 & 9 & 39.1 & -21.2 \\
$>\mathbf{2 0}$ & 4 & 5.1 & 1 & 4.3 & 0.8 \\
\hline Total & $\mathbf{7 8}$ & $\mathbf{1 0 0 . 0}$ & $\mathbf{2 3}$ & $\mathbf{1 0 0 . 0}$ & $\mathbf{0 . 0}$ \\
\hline
\end{tabular}

Note. ${ }^{1} \mathrm{SA}>2.7$ : Number of weeks when the observed aphid population was greater than the mean number of aphids during the entire sampling period (2.7 aphids/trap); ${ }^{2}$ Deviation \%: \% SA - \% SA $>2.7$.

\section{Conclusion}

In conclusion populations of aphids in winter cereals in southern Brazil have changed radically. The devastating populations of $M$. dirhodum during the boom years of wheat cropping have been reduced to such levels that rarely need to be controlled. The vacated niche and changes in the production system were optimal for $R$. padi, a species adapted to colonize different hosts, and which became the predominant species with the greatest seasonal distribution. For other species its occurrence was limited to certain seasons and stages of their hosts. Populations of aphids above the average for the period were predominantly found when rainfall remained between $0-20 \mathrm{~mm}$ and the average temperatures between $15-20^{\circ} \mathrm{C}$.

\section{References}

Alves, L. F. A., Prestes, T. M. V., Zanini, A., Dalmolin, M. F., \& Menezes, J. A. O. (2005). Controle biológico natural de pulgões (Hemiptera: Aphididae) em lavoura de trigo por parasitóides (Hymenoptera, Aphidiinae), 
no município de Medianeira, PR, Brasil. Semina: Ciências Agrárias, 26, 155-160. http://dx.doi.org/10.5433/1679-0359.2005v26n2p155

Blackman, R. L., \& Eastop, V. F. (1984). Aphids on the world's crops: An identification and information guide. Chichester: John Wiley \& Sons.

Brabec, M., Honek, A., Pekar, S., \& Martinkova, Z. (2014). Population Dynamics of Aphids on Cereals: Digging in the Time-Series Data to Reveal Population Regulation Caused by Temperature. PLoS ONE, 9(9), e106228. http://dx.doi.org/10.1371/journal.pone.0106228

Caetano, V. R. (1968). Nota prévia sobre a ocorrência de uma virose em cereais de inverno no Rio Grande do Sul. Revista da Sociedade Brasileira de Fitopatologia, 2, 67-75.

Caetano, V. R. (1972). Estudo sobre o vírus do nanismo amarelo da cevada, em trigo, no Rio Grande do Sul [A study of Barley yellow dwarf virus in wheat in Rio Grande do Sul]. (Unpublished doctoral dissertation), Escola Superior de Agricultura "Luiz de Queiróz", Piracicaba, Brazil.

Caetano, V. R. (1973). Estudos sobre os afidios vectores do Vírus do Nanismo Amarelo da Cevada em especial de Acyrthosiphon dirhodum, em trigo, no Sul do Brasil [Studies on the aphids vectors of Barley yellow dwarf virus especially Acyrthosiphon dirhodum, in wheat in southern Brazil]. (Unpublished doctoral dissertation), Universidade Estadual de Campinas, Brazil.

Caetano, V. R., \& Caetano, V. R. (1978). Variações sazonais de pulgões de trigo [Seasonal variations of wheat aphids]. Solos e técnicas culturais, economia e sanidade (pp. 102-114). Embrapa Centro Nacional de Pesquisa de Trigo, Passo Fundo, Brazil.

Corseuil, E. (1959). Pragas que atacam os trigais. Boletim do Campo, 15, 3-9.

Dixon, A. F. G. (1977). Aphid ecology: Life Cycles, Polymorphism, and Population Regulation. Annual Review of Ecology and Systematics, 8, 329-353. http://dx.doi.org/10.1146/annurev.es.08.110177.001553

Fehn, L. M. (1970). Estudo da ação de inseticidas granulados, sistêmicos e de profundidade, no controle de pulgões, em trigo. Pesquisa Agropecuária Brasileira, 5, 259-264.

Finlay, K. J., \& Luck, J. E. (2011). Response of the bird cherry oat aphid (Rhopalosiphum padi) to climate change in relation to pest status, vectoring potential and function in a crop-vector-virus pathosystem. Agriculture, Ecosystems \& Environment, 144, 405-421. http://dx.doi.org/10.1016/j.agee.2011.08.011

Gassen, D. N. (1984). Insetos associados à cultura do trigo no Brasil, EMBRAPA/CNPT. Passo Fundo. Circular Técnica n. 3, julho.

Kober, E. A. M. (1972). Combate aos pulgões que atacam o trigo (p. 9). Secretaria da Agricultura do Estado do Rio Grande do Sul, Supervisão da Produção Vegetal, Unidade de Defesa e Fomento, Equipe de Defesa Fitossanitária, Porto Alegre.

Lau, D., Pereira, P. R. V. da S., Salvadori, J. R., Schons, J., Parizoto, G., \& Mar, T. B. (2009). Ocorrência do Barley/Cereal yellow dwarf virus e seus vetores em cereais de inverno no Rio Grande do Sul, Santa Catarina, Paraná e Mato Grosso do Sul em 2008. Retrieved July 15, 2015, from http://www.cnpt.embrapa.br/biblio/co/p_co256.htm

Leslie, T. W., Van Der Werf, W., Bianchi, F. J. J. A., \& Honek, A. (2009). Population dynamics of cereal aphids: Influence of a shared predator and weather. Agricultural and Forest Entomology, 11, 73-82. http://dx.doi.org/10.1111/j.1461-9563.2008.00405.x

Parizoto, G., Rebonatto, A., Schons, J., \& Lau, D. (2013). Barley yellow dwarf virus-PAV in Brazil: seasonal fluctuation and biological characteristics. Tropical Plant Pathology, 38, 11-19. http://dx.doi.org/10.1590/S1982-56762013000100002.

Pereira, P. R. V. S., Salvadori, J. R., \& Lau, D. (2008). Pulgão-preto-dos-cereais, Sipha maydis Passerini 1860 (Hemiptera: Aphididae). Embrapa Trigo, Passo Fundo, Brazil Folder. Retrieved July 15, 2015, from http://www.infoteca.cnptia.embrapa.br/handle/doc/842847

Pereira, P. R. V. da S., Salvadori, J. R., \& Lau, D. (2009). Identificação de adultos ápteros e alados das principais espécies de afideos (Hemiptera: Aphididae) associadas a cereais de inverno no Brasil. Retrieved July 15, 2015 from http://www.cnpt.embrapa.br/biblio/co/p_co258.pdf

Pimenta, H. R., \& Smith, J. G. (1976). Afideos, seus danos e inimigos naturais em plantações de trigo (Triticum sp.) no Estado do Paraná (p. 175). Ocepar, Curitiba. 
Reiniger, C. H. (1941). Uma ameaça para os trigais do Sul. Combate biológico dos pulgões (afídeos). Chácaras e Quintais, 64, 697-699.

Risch, S. J. (1987). Agricultural ecology and insect outbreaks. In P. Barbosa \& J. C. Schultz (Eds.), Insect outbreaks (pp. 217-238). Academic Press, San Diego. http://dx.doi.org/10.1016/b978-0-12-078148-5.50013-0

Salvadori, J. R., \& Salles, L. A. B. (2002). Controle biológico de pulgões do trigo. In J. R. P. Parra, P. S. M. Botelho, B. S. Corrêa-Ferreira \& J. M. S. Bento (Eds.), Controle biológico no Brasil: Parasitóides e predadores (pp. 427-477). Manole, São Paulo.

Silva, M. T. B., Costa, E. C., Balardin, R. S. (2004). Cultivars reaction and efficiency of chemical control of aphids vectors of Barley yellow dwarf virus in wheat. Ciência Rural, 34, 1333-1340. http://dx.doi.org/10.1590/S0103-84782004000500003

Stoetzel, M. B. (1987). Information on and identification of Diuraphis noxia (Homoptera: Aphididae) and other aphid species colonizing leaves of wheat and barley in the United States. Journal of Economic Entomology, 80, 696-704. http://dx.doi.org/10.1093/jee/80.3.696

Stoetzel, M. B., \& Miller, G. L. (2001). Aerial feeding aphids of corn in the United States with reference of the root-feeding Aphis maidiradicis (Homoptera: Aphididae). Florida Entomological Society, 84, 83-98. http://dx.doi.org/10.2307/3496667

Walker, G. P., Nault, L. R., \& Simonet, D. E. (1984). Natural mortally factors acting on potato aphid (Macrosiphum euphorbiae) populations in processing-tomato fields in Ohio. Environmental Entomology, 13, 724-732. http://dx.doi.org/10.1093/ee/13.3.724

\section{Copyrights}

Copyright for this article is retained by the author(s), with first publication rights granted to the journal.

This is an open-access article distributed under the terms and conditions of the Creative Commons Attribution license (http://creativecommons.org/licenses/by/3.0/). 